Article

\title{
Spatial Analysis of the Empirical Behavior of Municipal Institutional Capacity for the Formulation of Sustainable Growth Management Strategies with a Regional Focus: State of Veracruz, Mexico
}

\author{
Isabel Lagunes-Gómez ${ }^{1}{ }^{(0)}$, María Graciela Hernández-Orduña ${ }^{1, *}{ }^{\mathbb{C}}$, Rene Murrieta-Galindo ${ }^{1}$, \\ Daniel Hernández-Pitalua ${ }^{1}\left[1\right.$ and Darwin Mayorga-Cruz ${ }^{2}$ \\ 1 Sustainable Regional Development, El Colegio de Veracruz, Xalapa-Enríquez 91000, Mexico; \\ ilagunes@msev.gob.mx (I.L.-G.); dpitalua3@gmail.com (D.H.-P.); murrieta13@gmail.com (R.M.-G.) \\ 2 Consejo Veracruzano de Investigación Científica y Desarrollo Tecnológico, Xalapa-Enríquez 91069, Mexico; \\ dmayorga@coveicydet.gob.mx \\ * Correspondence: gracielahernandez.orduna@gmail.com; Tel.: +52-228-194-9954
}

Citation: Lagunes-Gómez, I.; Hernández-Orduña, M.G.; MurrietaGalindo, R.; Hernández-Pitalua, D.; Mayorga-Cruz, D. Spatial Analysis of the Empirical Behavior of Municipal Institutional Capacity for the Formulation of Sustainable Growth Management Strategies with a Regional Focus: State of Veracruz, Mexico. Sustainability 2022, 14, 2000 https://doi.org/10.3390/su14042000

Academic Editor: Wann-Ming Wey

Received: 5 December 2021

Accepted: 30 January 2022

Published: 10 February 2022

Publisher's Note: MDPI stays neutral with regard to jurisdictional claims in published maps and institutional affiliations.

Copyright: (C) 2022 by the authors. Licensee MDPI, Basel, Switzerland. This article is an open access article distributed under the terms and conditions of the Creative Commons Attribution (CC BY) license (https:// creativecommons.org/licenses/by/ $4.0 /)$.

\begin{abstract}
As a governmental function, development for progress and welfare is a highly complex process that involves updating various attributes (such as a paradigm, critical or alternative, depending on of the way in which they are articulated regarding social aspects, environmental, and economic growth, as well as the institutional capacity of public and private actors). Regarding this, we are interested in the municipal institutional capacity (MIC) as a skill to carry out the functions and appropriate tasks that municipalities must fulfill in an effective, efficient, and sustainable way, and it varies considerably, depending on each local context. In order to analyze the relevance of the current official regionalization as a state government strategy for the centralized construction of MIC, an exploratory approach to its spatial behavior in the State of Veracruz, Mexico, was carried out. Given the nature of the study, a purely mixed approach, sequential exploratory design, subnational analysis methodology, and exploratory spatial data analysis (ESDA) were employed. The variable to be analyzed is the 2016 Municipal Functional Capacities Index (Índice de Capacidades Funcionales Municipales (ICFM)), with the Geostatistics Framework cartographic base of the 2020 Population and Housing Census. The analysis units are 212 municipalities in the 2014-2017 government period. As a result, it was confirmed that the current regionalization was irrelevant, owing to the absence of global spatial autocorrelation, and it was concluded that targeted interventions are necessary according to regional modeling techniques, based on scientific evidence.
\end{abstract}

Keywords: spatial analysis; subnational analysis; municipal institutional capacity; focus on evidence-based policy; municipal capacity building

\section{Introduction}

Institutional capacity (IC) is a common public management issue [1] that has gained space in development studies (the form of development that we mean is the development for progress and welfare, as conceived in The United Nations Global Goals for Sustainable Development (SDGs)) as both a theoretical question and operational concern, as there is consensus that conditions the results of government action [2-12]. Therefore, the strengthening of government capacities to manage development stands out in the objectives of various national and international projects that constitute axes of politics and contemporary public administration in Mexico such as the Sustainable Development Goals (SDG), the plans of development of the state and national government levels, as well as their sectoral and specific programs (Appendix A, Table A1).

Different authors agreed that the ICs vary considerably depending on each local context [2,13-16], which explains the increase in the number of studies on determining 
factors of IC; thus, they proliferated from a theoretical $[1,10,12,17-19]$ and empirical perspective $[2,6,13,20,21]$.

Mexico is a federal republic, and its administrative classification is composed of 1 Mexico City and 31 free and sovereign states but subject to the Federal Pact. States are composed of municipalities. However, in México, there are few IC studies focused on subnational governments, especially on the municipal government level, as described in the background section, despite the fact that the municipality constitutes the basis of the territorial division and the political and administrative organization, and is in charge of the provision of basic public services such as drinking water, drainage, sewerage, treatment and disposal of its wastewater; street lighting; clean, collection, transfer, treatment and final disposal of waste; markets and supply centers; cemeteries; slaughterhouses; streets, parks, gardens, equipment, and public security.

Having established the above, we can understand the impact of the performance of municipal governments on people's quality of life and that the gap in their knowledge in the Mexican case is especially worrying if we also take into account that (1) according to the Municipal Functional Capacities Index (Índice de Capacidades Funcionales Municipales (ICFM)) (United Nations Development Programme (UNDP)) [7], the national average of the capacities of the municipalities is low (from 0.374 on a scale of zero to one, where zero is nothing and one is the ideal capacity) and, at a glance, it shows disparities or dissimilarities between the states since the historical participation in federal programs aimed at building MIC (2016-2020) and dispersion patterns; (2) their participation in these programs is decreasing [22-25] (Appendix B, Figure A1) and has presented an unstructured pattern in the last five years [22-25] (Appendix B, Figure A2).

Having established this paradox, on the one hand, the impact of local capacities in the management of sustainable development is recognized and, on the other hand, praxis reveals a research gap. Therefore, we consider this situation a limitation in the already complex task of "leaving no one behind". In addition, we argue that the study of the MIC requires academic and governmental attention, and, as an obligatory step in the subnational analysis (SNA) or subnational research (SNR) of social phenomena (in line with what is proposed by Giraudy, Moncada, and Snyder [26], Harbers and Ingram [27], and Acevedo Bohórquez and Velásquez Ceballos [28]), in this study, we propose to study its distribution in the territory to warn more clearly about phenomena that are occurring at local levels in order to offer recommendations that allow attention priority to spaces where real development possibilities are affected. In our case, this is owing to a greater Institutional Capacity Deficit (ICD). Specifically, the study of the MIC in the State of Veracruz (Appendix C) is of interest to us, as it has been among the lowest levels of participation in federal programs for the development of MIC during the last five years (Appendix B, Table A2).

Our objective is to describe the spatial behavior of IC in the municipalities of this state in the 2014-2017 government period, with the aim of analyzing the relevance of the current official regionalization as a state government strategy for the centralized construction of MIC and, where appropriate, present findings that may serve as support for the creation of rectification policies with a regional focus, in accordance with the empirical behavior of the MIC. It is important to emphasize that we are not seeking a generalizable result with external validity. This study constitutes the first approach toward a state that preserves the institutional capacities in the research context and will serve as a basis for establishing priorities and identifying promissory concepts and variables for future lines of research.

\section{Materials and Methods}

An exploratory study with a descriptive scope of the spatial behavior of institutional capacities was carried out in the universe of the 212 municipalities of the State of Veracruz, Mexico, government period 2014-2017. To achieve a broader and deeper perspective of the phenomenon, a "purely" mixed approach (QUAL-QUAN) and a sequential exploratory design (SEXPLOD) comparative modality [29] were used in two stages. This approach was 
used with claims of triangulation or increased validity, complementation, contextualization, and discovery and confirmation [29].

The first qualitative stage comprised the exploration of the theoretical approaches on institutional capacity, a focus on evidence-based policy, subnational analysis, exploratory spatial data analysis (ESDA), and background review through the collection and analysis of scientific sources such as journals and books in the ScienceDirect, Elsevier, and Google Scholar repositories, as well as the review of official, normative, and technical documents in national and international electronic institutional repositories such as the United Nations Development Programme (UNDP), the Government of Mexico, and the Government of the State of Veracruz.

This stage was supported by methods of content analysis and structured observation through data record techniques and file review. The results served as a basis for generating hypotheses that were tested in the second phase.

In the second phase, subnational analysis (SNA) was used as a research strategy for its usefulness to observe variations in relevant processes within countries [26]. In the election of SNA, its affinity with mixed methods was also considered [26,27]. The SNA research strategy makes it possible to operationalize theoretical models in order to know the state of the MIC in subnational spheres, either by breaking down capacity into dimensions and analyzing one or more of these in a particular way or by analyzing IC from a perspective comprehensive, where we proposed the ICFM as an index that supports and integrates 5 dimensions. These dimensions of capacity are (1) involvement of relevant actors; (2) identification; (3) formulation of policies and strategies; (4) budget, management, and implementation; (5) evaluation. Thus, to consult the ICFM methodology in an extensive detail, it can be carried out in the Informe de Desarrollo Humano Municipal 2010-2015 Transformando México desde lo local [7].

Therefore, the gap in our research design is understanding the dimensions separately, since we study the MIC using an integral index.

At this second phase, as an obligatory step in the scientific study of politics and development, the spatial behavior of MIC was described, spatial data were transformed into information with the support of the GeoDa spatial analysis software, and hypotheses were tested through quantitative analysis of spatial data patterns and graphical and statistical techniques. Among the indices to analyze spatial autocorrelation, the Moran's Index was used, as it is one of the best known and most widespread for this type of analysis. A characteristic of this index is that only the values of the analysis units, determined from the neighborhood criterion, are taken into account.

Finally, the results were contrasted with the theoretical approaches on institutional capacities to determine relevant information for the selection of modeling techniques based on scientific evidence, as further research.

The ICFM was built from the National Census of Municipal and Delegational Governments of the National Institute of Statistics and Geography (Instituto Nacional de Estadística y Geografía ((INEGI), 2017). The census gathers information through questionnaires answered directly by the bureaucrats; therefore, it entails at least two types of bias: (1) the bureaucrats limited to rationality and (2) the bureaucrat's uncertainty regarding the penalty or compensation for the response.

\section{Results}

\subsection{First Stage: Review of Theoretical Bases and Antecedents}

The perception regarding development presented in this study is congruent with the one proposed by Mujica and Rincón [30], as a deliberate, multidimensional process of social change and structure and equalization of opportunities to promote capacities. IC studies seek to identify the institutional capacity deficit (ICD) [31] which, according to Oszlak and Orellana [32], could prevent or affect the performance of certain functions or the conclusion of programs or projects in development management. These gaps correspond to what Aguilar Villanueva [3] calls the institutional underdevelopment of the state. 
Of course, in addressing the ICD problem, we consider essential the application of the evidence-based policy (EBP) approach, which claims that political actions must be supported by scientific knowledge in order to improve [33]. In this sense, it is also worth highlighting the importance of the application of the subnational analysis (SNA) strategy, which leads to a better understanding of the spatially uneven nature of contemporary transformations [27] and of spatial analysis, which studies the relationships between variables whose data are georeferenced and allow identifying the different spatial distributions of the variables and the importance that the spatial component exerts in these distribution patterns. According to Giraudy et al. [26] and Harbers and Ingram [27], the explanation of the spatial behavior of phenomena is an obligatory step in the scientific study of politics and development when variables related to geographic information (georeferenced data) are involved given that, by means of this, we can explicitly keep the concept of territory present in the analyses. Acevedo Bohórquez and Velásquez Ceballos [28], Giraudy et al. [26], and Harbers and Ingram [27] coincide in pointing out that studying subnational politics in a disciplined and evidence-based way implies evaluating the spatial effects through ESDA to avoid the risk of treating subnational units of analysis as independently distributed observations without previously considering the effect of spatial structures on the results, relationships of interest, and design and evaluation of analytical models. Therefore, supported by these authors, we considered that the information obtained in this way represents a valuable input for the formulation of correction strategies based on evidence, as it allows us to select an approach in accordance with the behavior of the data, whether it is national or subnational, leading to the implementation of targeted policies.

According to Acevedo Bohórquez and Velásquez Ceballos [28], this georeferenced information can present two types of spatial effects: spatial dependence and spatial heterogeneity. Spatial heterogeneity is related to the absence of stability in the behavior of phenomena in space, that is, the spatial units under observation are far from being homogeneous. This implies that functional parameters and forms vary with location and are not homogeneous across data sets. While spatial dependence refers to the fact that the data observed at one point in space are dependent on values observed at other points.

As Nohlen and Sturm [15] suggest, the concept of structural heterogeneity (SH) as a descriptive category is incorporated into the theoretical debate on development to designate a characteristic referred to a state of affairs and is used to explain asymmetric relationships such as different levels of development and imbalances in key development factors. Thus, it is particularly important for this study. Taking Montañez Gómez and Delgado Mahecha [14] into account, we considered that these differences between spaces require different levels of protection and encouragement to achieve equal opportunities for development.

Spatial dependence and spatial heterogeneity were analyzed in terms of spatial autocorrelation or spatial correlation. The main difference between the two is the univariate nature of the autocorrelation and the multivariate nature of the correlation (for a more in-depth study, refer to Siabato and Guzmán-Manrique [34]).

By means of spatial autocorrelation, the variability of a phenomenon through geographic space was analyzed in order to determine spatial patterns and describe their behavior [34], measuring the degree to which a variable correlates with itself in geographic space. Based on Siabato and Guzmán-Manrique [34], in practical terms, we can state that when the phenomenon tends to form conglomerates or clusters, autocorrelation is positive; if the phenomenon tends to be dispersed, the spatial autocorrelation is negative. However, when the phenomenon behaves randomly, without defined or structured behavior, there is no spatial autocorrelation.

In the literature, it was found that interest in studies that seek to evaluate the results of development in local governments based on their institutional capacities is recent in Latin America. In Cuba, prominent research includes a study by González Pérez et al. [35], which was carried out on the Bayamo municipality, and a case study of intervention, carried out on the Urbano Noris municipality by the Municipal Technical Group [36]. In Peru, the literature is more extensive, and the studies that stand out include those carried out on the 
district of Chavín de Huantar [37], the municipal government of the Province of Jaén [38], the Province of Chupaca [39], the District Municipality of Matapalo [40], and the district of Supe [41]. These studies have empirically verified the relationship between functional capacities and developmental outcomes.

In the case of Mexico, at the subnational level, there is a study of management capacities for development that analyzes the management components and their deficiencies in the Metropolitan Area of Toluca [42]. Furthermore, there are two MIC diagnostic studies that included the total number of municipalities with national coverage: the ICFM carried out by the UNDP, with data from 2016 [7], and the IDIM carried out by the Superior Audit of the Federation (Auditoría Superior de la Federación (ASF)), with data from 2013 [4]. Additionally, noteworthy, at the national level, are the programs that the National Institute for Federalism and Municipal Development (Instituto Nacional para el Federalismo y el Desarrollo Municipal (INAFED)) has implemented since 2004 (Table 1 to identify and develop the management capacities of municipalities throughout the country, based on their voluntary incorporation-a condition that has caused participation to be presented as an unstructured pattern among states (Appendix B, Figure A2). At an international level, these programs include the ISO 18091:2019 Quality management systems-Guidelines for the application of ISO 9001 in the local government and the same ISO 9001: 2015, Quality management systems-Requirements [43].

Table 1. National programs for the development of management capacities in municipalities.

\begin{tabular}{cc}
\hline Program & Period of Validity \\
\hline Municipal Performance Advisory Guide & $(2019,--)$ \\
Agenda for Municipal Development Program & $(2014-2018)$ \\
Agenda Program From the Local & $(2004-2013)$ \\
\hline Source: Authors' elaboration based on INAFED [44]
\end{tabular}

Hence, although references were found in the study of municipal government capacities, none were found from the perspective of the SNA using the spatial approach as a tool to support the construction of institutional capacity. Thus, the address of the problem from the proposed approach is innovative.

On the other hand, it was found that the State of Veracruz has undergone regionalization for various purposes: geomorphological purposes, considering 37 units belonging to 6 geomorphological provinces with 9 subprovinces [45]; cartographic landscape maps [46]; administrative purposes in terms of development planning, considering 10 regions [47], and recently, for the purposes of economic reactivation and return to the new normality, considering 5 regions [48].

The administrative regionalization based on 10 regions determined by criteria of geographic neighborhoods (as well as that based on 5 regions), was used for general purposes by different entities belonging to the Government of the State of Veracruz since 2005, promoted by the Statistical Information Center and Geographical of the State of Veracruz (CEIEG) [49], with some exceptions such as electoral, economic reactivation, and return to the new normality.

\subsection{Second Stage: Spatial Analysis and Hypothesis Testing}

The findings of the first stage of the study served as the basis for generating the following hypotheses:

H0. There is no spatial autocorrelation in the IC of the 212 municipalities of the State of Veracruz, Mexico in the 2014-2017 government period.

H1. There is a spatial autocorrelation in the IC of the 212 municipalities of the State of Veracruz, Mexico, in the 2014-2017 government period. 
It is worth mentioning that in determining the territorial units of analysis, the theoretical considerations proposed by Giraudy et al. [26] were taken into account (Table 2). In the selection of the IC database with municipal subnational disaggregation level, compliance with the greater number of practical criteria proposed by Harbers and Ingram [27] (Table 3) and the most up-to-date extracted information were considered (in this respect, it is important to consider that, although the INAFED programs are updated annually, they only contain data from the municipalities that join voluntarily, as the participation of the municipalities of Veracruz has fluctuated between $6 \%$ and $4 \%$ from 2016 to 2020; therefore, it was considered an insufficient sample to achieve representativeness of the data (Appendix B, Table A2).

Table 2. Description of analysis units.

\begin{tabular}{cc}
\hline Theoretical Considerations & Determination of Analysis Unit \\
\hline Type: & Formal or jurisdictional \\
Level: & Subnational \\
Variety: & Political and administrative unit; municipalities \\
Number of levels of analysis: & Single level (Municipal) \\
\hline Source: Authors' elaboration based on Giraudy et al. [26].
\end{tabular}

Source: Authors' elaboration based on Giraudy et al. [26].

Table 3. Compliance of the MIC databases with the practical criteria proposed by Harbers and Ingram [27]. Case of municipalities of the State of Veracruz, Mexico.

\begin{tabular}{|c|c|c|c|}
\hline Criteria & INAFED Programs & $\begin{array}{c}\text { Municipal Institutional } \\
\text { Development Index (IDIM) }\end{array}$ & $\begin{array}{l}\text { Municipal Functional } \\
\text { Capacities Index (ICFM) }\end{array}$ \\
\hline Observation maximization & No * & Yes & Yes \\
\hline Complete contiguity of areas & No * & Yes & Yes \\
\hline $\begin{array}{c}\text { Maximization of } \\
\text { comparability with studies }\end{array}$ & No * & Yes & Yes \\
\hline $\begin{array}{l}\text { Maximization of } \\
\text { temporal stability }\end{array}$ & Yes & No ** & No $* * *$ \\
\hline Scalability & $\mathrm{No}^{*}$ & $\mathrm{No}^{* *}$ & Yes \\
\hline Agent Responsible: & $\begin{array}{l}\text { National Institute for } \\
\text { Federalism and } \\
\text { Municipal Development } \\
\text { (INAFED) }\end{array}$ & $\begin{array}{l}\text { Superior Audit of the } \\
\text { Federation } \\
\text { (ASF) }\end{array}$ & $\begin{array}{c}\text { United Nations } \\
\text { Development Programme } \\
\text { (UNDP) }\end{array}$ \\
\hline
\end{tabular}

* Due to the scarce participation of the municipalities in the programs promoted by INAFED, there are data for a maximum of $6 \%$ of the municipalities in the State of Veracruz between 2016 and 2020. Therefore, it was considered an insufficient sample to achieve representativeness of the data. ${ }^{* *}$ Published for the first and only time in 2015, with data collected in 2013. This information is consistent with the 2010-2013 government period. *** Published for the first and only time in 2019, with data collected in 2016. This information is consistent with the 2014-2017 municipal government period. Source: Authors' elaboration based on Harbers and Ingram [27], INAFED [44], ASF [4], and UNDP [7].

Hence, the units of analysis are 212 municipalities of the State of Veracruz, Mexico, in the 2014-2017 government period (Appendix B). The variable to be analyzed is the ICFM 2016 [7] (available for download at https://www.mx.undp.org/content/mexico/es/home/1 ibrary / poverty /informe-de-desarrollo-humano-municipal-2010-2015--transformando-.html, accessed on 29 January 2022), while the cartographic base is the Geostatistical Framework of the Population and Housing Census 2020 [50], coverage of the State of Veracruz (this cartographic base was used given that the municipal division remains unchanged since 2004, with the creation of the municipalities of San Rafael and Santiago Sochiapan).

The main results of the quantitative analysis of spatial patterns carried out using the free software GeoDa 1.18 (6/16/2021) for Mac OS X 11 (Big Sur) are presented below.

\subsubsection{Global Autocorrelation}

From the first law of geography proposed by Tobler ("Everything is related to everything else, but things that are close are more related than things that are far away", 
1970, cited in by Siabato and Guzmán-Manrique [34]), a first-order queen-type contiguity matrix using the physical neighborhood criterion was considered, and a matrix (W) of $212 \times 212$ was defined, according to the number of analysis units (Table 4); that is, to quantify spatial autocorrelation and define it as non-existent, positive, or negative, the ICFM of each municipality was compared with those of their bordering neighbors, as can be seen in Figure 1.

Table 4. Properties of the first-order queen-type contiguity matrix.

\begin{tabular}{ll}
\hline Property & Value \\
Type & Queen \\
Symmetry & Symmetric \\
File & ICFM_2016Q1.gal \\
Id variable & CVEGEO \\
Order & 1 \\
\# Observations & 212 \\
Min neighbors & 1 \\
Max neighbors & 12 \\
Mean neighbors & 5.15 \\
Median neighbors & 5.00 \\
$\%$ Non-zero & $2.43 \%$ \\
\hline
\end{tabular}

Source: Authors' elaboration in GeoDa 1.18.

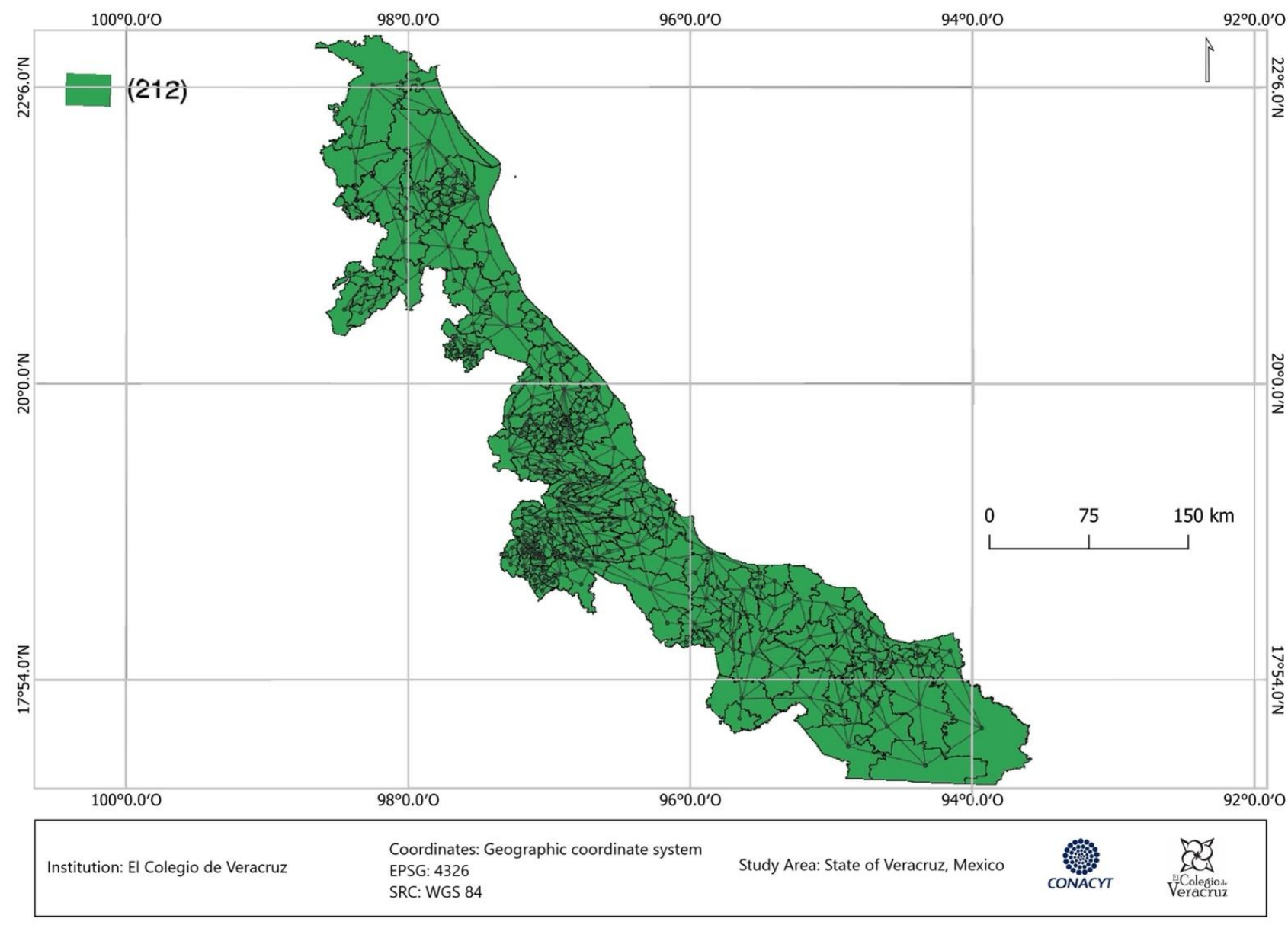

Figure 1. Connectivity map. First-order queen-type physical contiguity, elaborated in GeoDa 1.18.

\subsubsection{Hypothesis Testing}

The alternative hypothesis (H1) assumes that the spatial autocorrelation is different from 0 , and the null hypothesis (H0) assumes that the spatial autocorrelation is equal to 
0 . Therefore, to carry out the hypothesis test, we proceeded to calculate the univariate Moran's Index, obtaining 0.039 as a result (Figure 2).

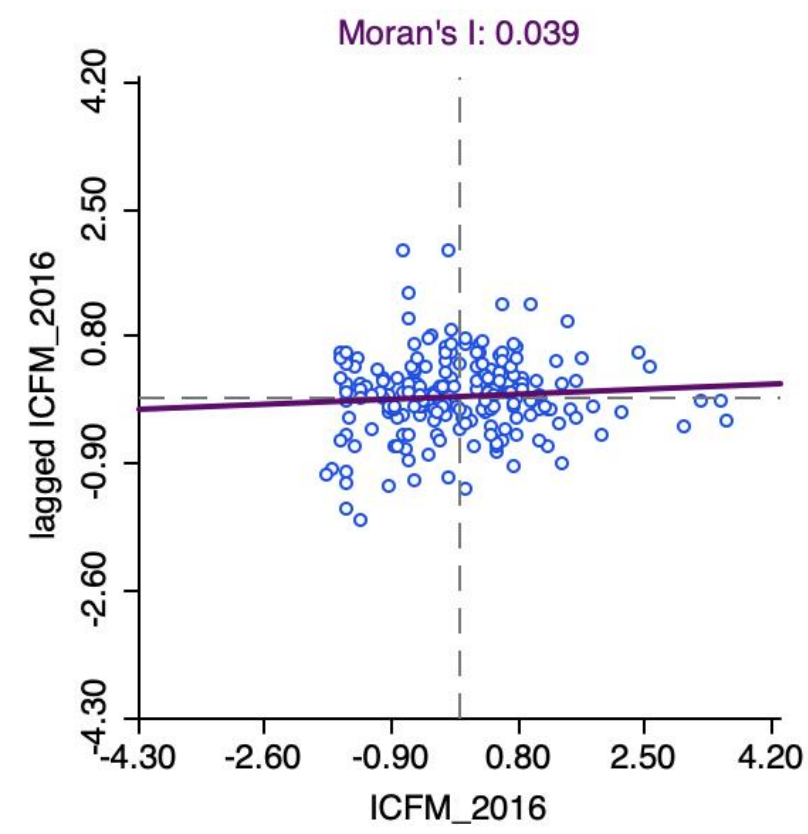

Figure 2. Moran's Index. First-order queen-type physical contiguity, elaborated in GeoDa 1.18.

Therefore, empirically, according to the interpretation proposal by Siabato and GuzmánManrique (Table 5, Translated into English), the IC of the 212 municipalities of the State of Veracruz, Mexico, in the 2014-2017 government period, present a random spatial behavior pattern: "as a general empirical recommendation, it is suggested to consider the randomness of the phenomenon when the index (Moran's Index) is in the range $-0.35 \leq \mathrm{I} \leq 0.35$. The higher and lower values should lead to considering cluster-type patterns $(\mathrm{I}>0.35)$ or dispersed patterns $(\mathrm{I}<-0.35)$, with clusters for positive values and dispersed for negative values" [34] (p. 11).

Table 5. Spatial patterns and spatial autocorrelation criteria linked to Moran's Index.

\begin{tabular}{ccc}
\hline & Spatial Patterns & \\
\hline Positive spatial autocorrelation & Negative spatial autocorrelation & No autocorrelation \\
\hline Cluster pattern & Dispersed pattern & Random pattern \\
\hline & Theoretical Moran Index \\
\hline $\mathrm{I}>0$ & $\mathrm{I}<0$ & $\mathrm{I}=0$ \\
\hline $\mathrm{I}>0.35$ & Moran index in practice & $-0.35 \leq \mathrm{I} \leq 0.35$
\end{tabular}

Source: Translated into English of Siabato and Guzmán-Manrique [34] (p. 12) used under Attribution-NonCommercialNoDerivatives 4.0 International (CC BY-NC-ND 4.0).

To interpret the value of the Moran's Index and give it statistical validity, based on Getis [51], Siabato and Guzmán-Manrique [34], and Huitrón Mendoza [52], a complete spatial randomness test (CSR) was carried out. Considering a confidence level of $99 \%$ and a significance level of 0.01 , the Monte Carlo simulation [53,54] was carried out as a reference distribution with 999 permutations (which can be understood as scenarios), a $z$-value of 1.0480, and a $p$-value of 0.15 (Figure 3) were obtained. According to Getis [51] and Celemín [54], if the $z$-value score or the $p$-value indicates statistical significance, the null hypothesis can be rejected. Given that the $p$-value did not update the assumption of 
being less than or equal to the level of significance [55], the statistical significance of the $z$-value was evaluated [56].

permutations: 999

pseudo $p$-value: 0.150000

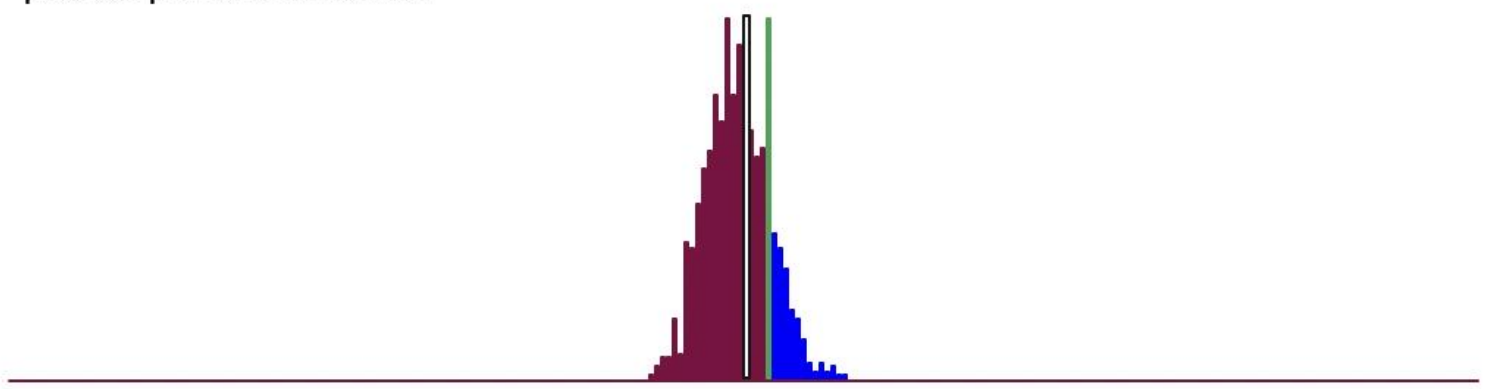

I: $0.0386 E[l]:-0.0047$ mean: -0.0074 sd: 0.0440 z-value: 1.0480

Figure 3. Reference statistical distribution graphic, designed on GeoDa 1.18.

According to the table listing critical values of standard normal distribution [51,56-58] for two-tailed situations [34], given that the critical value of $z$-value necessary to construct a distribution with a confidence value of $99 \%$ and a significance of 0.01 is 2.57 and $1.0480<2.57$, based on Getis [51], Anselin et al. [53], Celemín [54], Siabato y GuzmánManrique [34], and the statistical evidence, the null hypothesis (H0) of the absence of spatial autocorrelation was confirmed. The Critical Values of Standard Normal Distribution for Two-Tailed Situations can be found in Johnson and Kuby [59].

To corroborate that the result was not influenced by an inappropriate election of neighborhood matrix, the neighborhood criterion of first-order queen matrix was changed to first-order rook (Appendix D, Table A3, Figures A4 and A5, and it was observed that there were no significant changes, as the absence of spatial autocorrelation was confirmed with both arrangements.

Consequently, and in accordance with the three basic spatial patterns by Siabato and Guzmán-Manrique [34], in general, we can conclude that the ICFM variable behaves in space following a random pattern, as no defined or structured behavior was identified. The result of the analysis is statistically significant, with a confidence level of $99 \%$.

When analyzing the behavior by quadrant, it can be observed how this unstructured pattern manifests itself. Quadrant I shows the municipalities with a high ICFM whose neighboring municipalities have a high ICFM (Figure 4). Quadrant II shows the municipalities with a low ICFM surrounded by the municipalities with a high ICFM (Figure 5). Quadrant III shows the municipalities with a low ICFM surrounded by the municipalities with a low ICFM (Figure 6). Quadrant IV shows the municipalities with a high ICFM surrounded by the municipalities with a low ICFM (Figure 7). At this point, it is convenient to highlight that the ICFM classification as high or low obeys the level of the IC of each municipality of the research context in relation to those of the other municipalities of the State of Veracruz. Thus, it should not be assumed to be comparable to the classification of very high, high, medium, and low levels of the 2010-2015 Municipal Human Development Report Changing Mexico from the local by UNDP [7].

\subsubsection{Local Autocorrelation}

On the other hand, given the value of Moran's Index (0.039), it was considered convenient to analyze the local autocorrelation in order to investigate if there are any poles of attraction. Considering the same weight matrix with the physical neighborhood criterion in first-order queen contiguity (Table 4), a univariate local Moran's Index of 0.039 was obtained (Figure 8), and the following two clusters of interest were identified for future modeling in terms of the centralized impulse by the Instituto Veracruzano de Desarrollo 
Municipal (INVEDEM) as the main agency responsible for the construction of MIC in the research context (Figure 9):

(a) High-high cluster: integrated by the municipalities of Tlaltetela (0.249), Calcahualco (0.432), Coatzintla (0.314), Xico (0.274), and Lerdo de Tejada (0.364);

(b) Low-low cluster: integrated by the municipalities of Acultzingo (0.148), Amatitlán (0.013), Aquila (0.217), Atoyac (0.123), Carrillo Puerto (0.114), Cosamaloapan de Carpio (0.000), Cuitláhuac (0.053), Chacaltianguis (0.038), Ixmatlahuacan (0.025), Paso del Macho (0.142), José Azueta (0.127), Tierra Blanca (0.038), Tres Valles (0.064), and Carlos A. Carrillo (0.038).

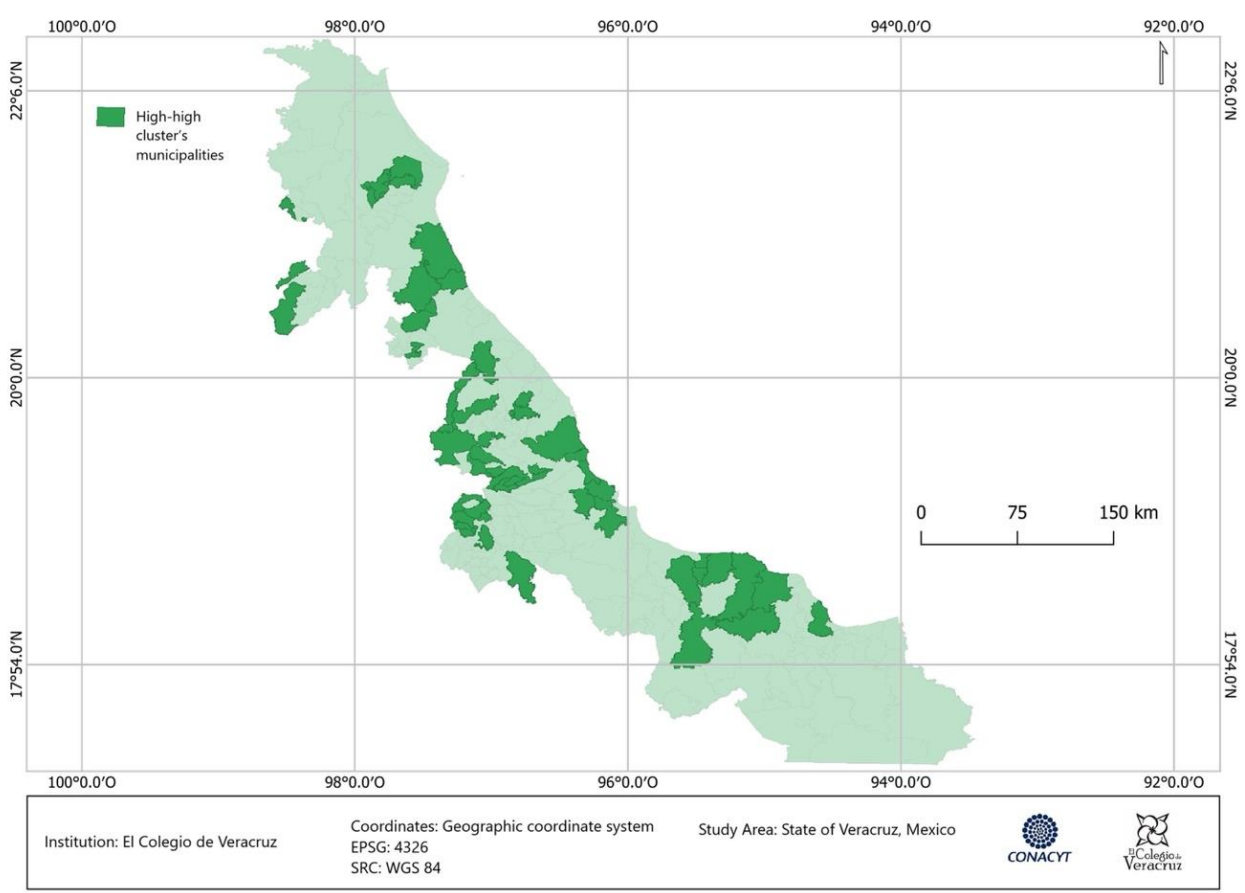

Figure 4. Quadrant I: high-high. Designed on GeoDa 1.18.

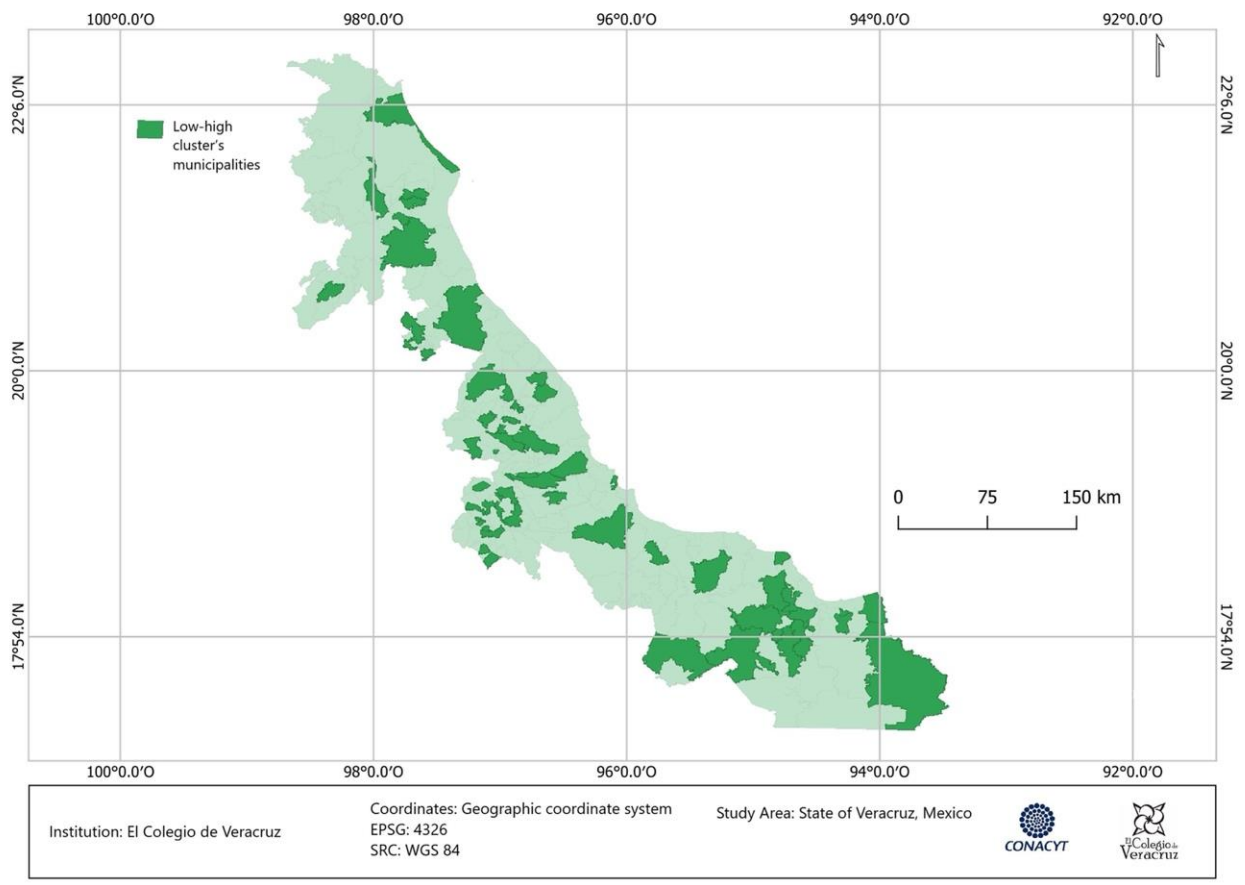

Figure 5. Quadrant II: low-high. Designed on GeoDa 1.18. 


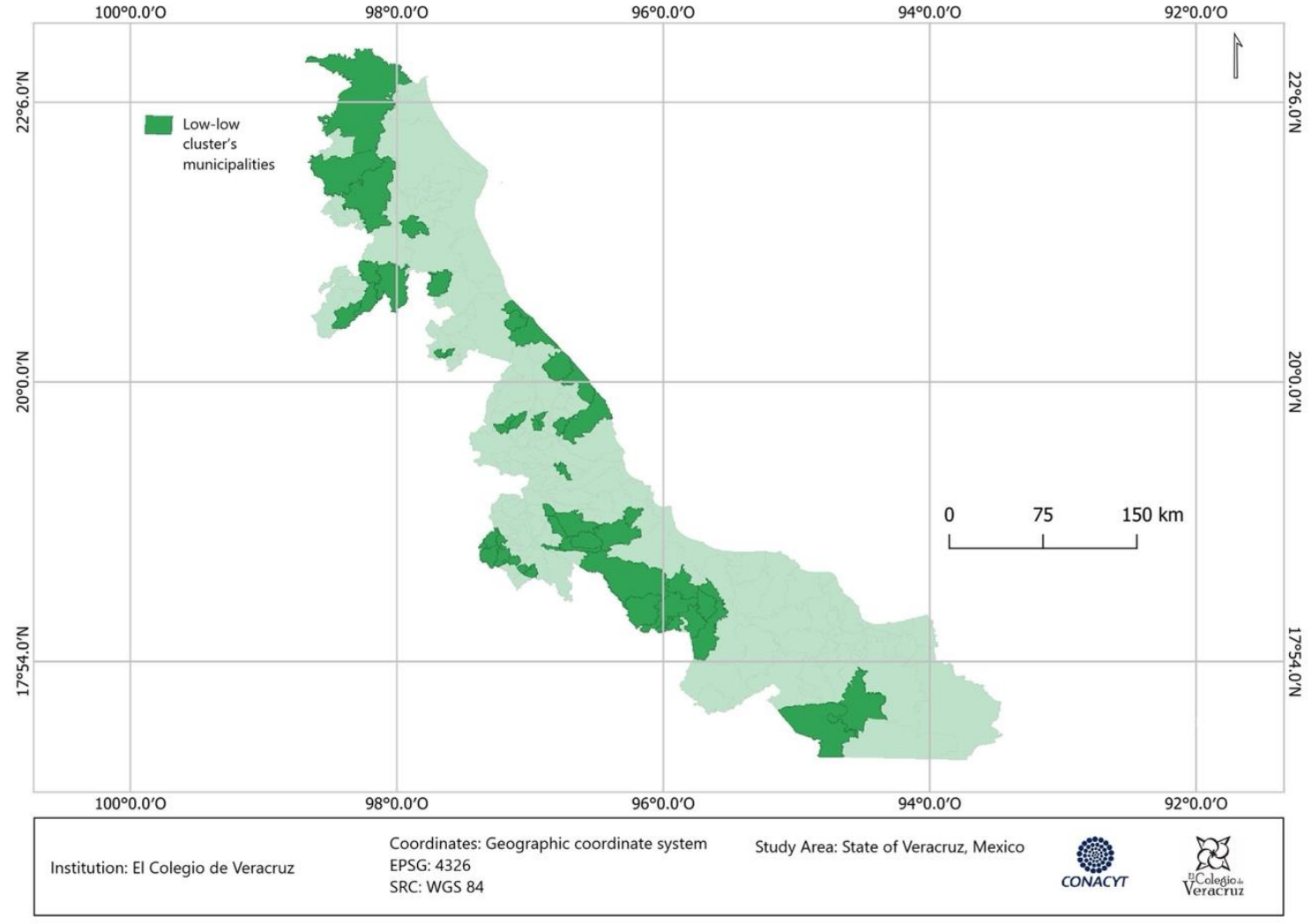

Figure 6. Quadrant III: low-low. Designed on GeoDa 1.18.

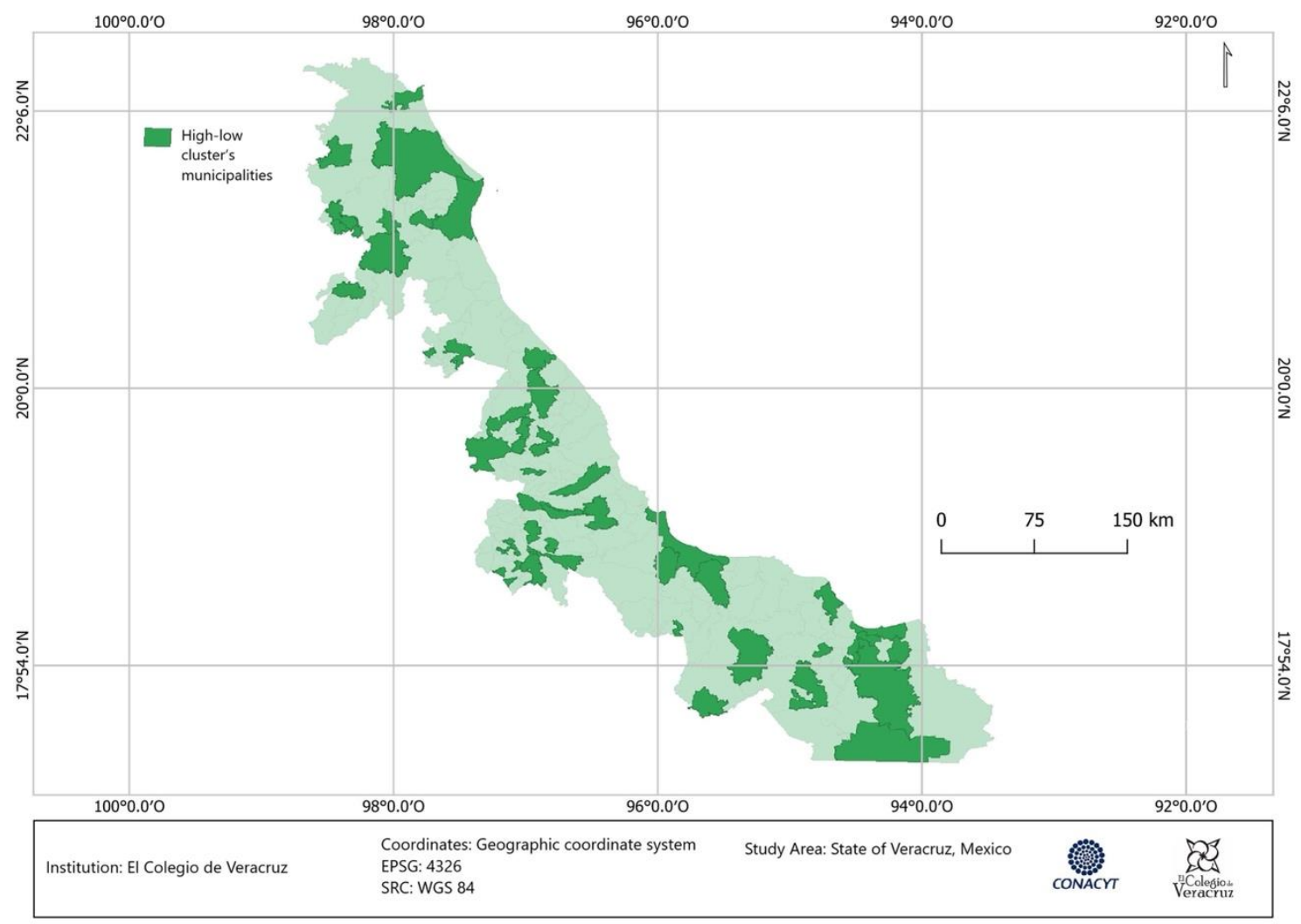

Figure 7. Quadrant IV: high-low. Designed on GeoDa 1.18. 


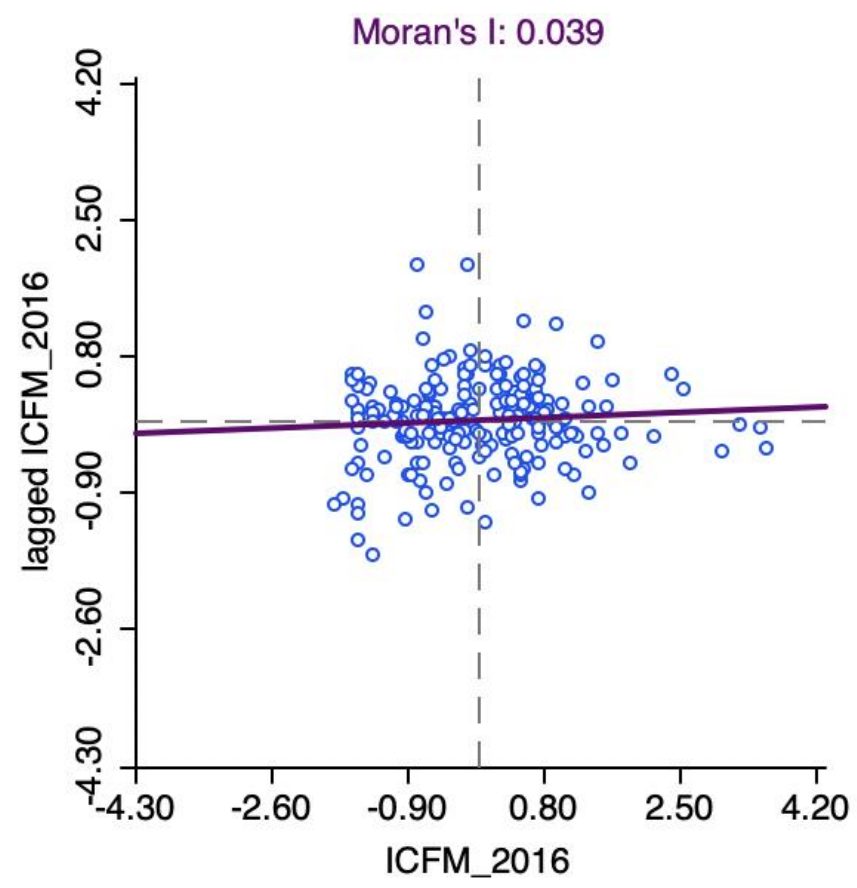

Figure 8. Univariate local Moran's Index. First-order queen-type physical contiguity. Designed on GeoDa 1.18.

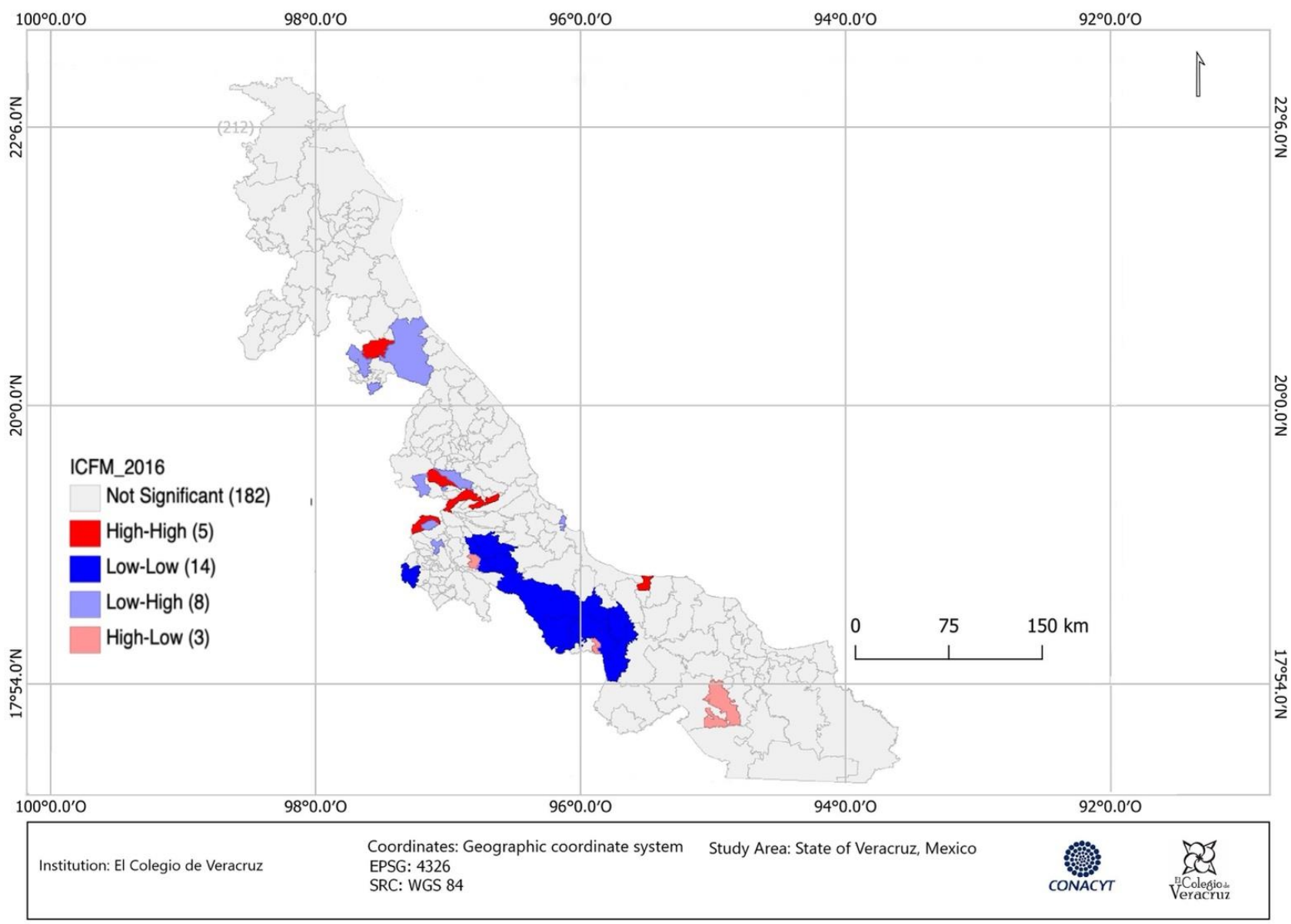

Figure 9. LISA Clusters Map. First-order queen-type physical contiguity. Designed on GeoDa 1.18. 


\section{Discussion}

Both empirically $(-0.35 \leq \mathrm{I} \leq 0.35)$ [34] and statistically (with $99 \%$ confidence level and 0.01 significance level), based on Getis [51], Anselin et al. [53], Celemín [54], Siabato y Guzmán-Manrique [34], the results confirmed that owing to the absence of global spatial autocorrelation, the institutional capacities of the municipalities of the State of Veracruz, Mexico, in the government period 2014-2017, presented a random spatial behavior pattern [34]. Thus, in agreement with Giraudy et al. [26], we argue that this result justifies a strategy of independent units in future work on modeling interventions for capacity building as "an empirical test that shows that the spatial dependence among the units is low or non-existent would constitute a solid basis for a strategy of the independent units." [26].

On the other hand, the assumption raised by Nohlen and Sturm [15] regarding structural heterogeneity owing to the presence of asymmetric relationships in MIC levels was also confirmed as a key factor in development-a situation that, according to Montañez Gómez and Delgado Mahecha [14], requires different levels of protection and encouragement to achieve equal opportunities for development. These asymmetries, according to John Rawls [60], are inequalities of the basic structure, where the principles of social justice must be applied at the first instance, and according to Amartya Sen [61], the most obvious inequalities are in distribution, which must be counterbalanced to approach equality of basic capabilities.

Findings will serve as bases for establishing priorities and identifying promissory concepts and variables to determine the regionalization model [62] with the best adjustment for the centralized promotion of IC in the municipalities in future scenarios.

\section{Conclusions}

Based on the findings and the proposals of the SNA and the EBP, we conclude that for the purposes of the study and management of the MIC, the current official regionalization of the State of Veracruz, Mexico, based on the criterion of geographic neighborhoods, results in an arbitrary delimitation of spatial units, given that it is not justified theoretically or empirically, as it is not consistent with the pattern of random spatial behavior observed.

In turn, we consider that the dispersion observed in the MIC levels and the fact that this is low on average confirms the presence of structural heterogeneity, and with it, spaces that, in order to achieve equal opportunities for development, deserve greater protection and encouragement than others. Thus, consistent with EBP, centralized promotion of MIC development requires data-supported regionalization. Hence, future research will consider regionalization modeling techniques for the centralized impulse of MIC suitable for differentiated attention, based on the grouping of municipalities according to their IC level. From the behavior of the data, we also deduced that the application of modeling according to independent units and based on a policy to promote equality, supported by scientific evidence, is of potential value to strengthen the results of capacity building actions of INVEDEM, as well as to seek greater protection and encouragement to the municipalities that most require it, in accordance with their particular conditions as sustainable growth management strategy with a regional focus. Hence, the main implication of this study of spatial analysis of the empirical behavior in the municipal institutional capacity is to reveal a promising line of research in order to formulate sustainable growth management strategies with a regional focus, based on evidence.

Finally, it is important to specify that although the State of Veracruz has MIC studies, they lack temporal stability. In this respect, it is important to emphasize the limitation that this condition represents for historical-comparative studies that allow finding determinant factors of MIC. Therefore, it is also essential to launch an appeal to INVEDEM, in order to address this issue and assume active participation and leadership within the projects established in the State Program of Statistics and Geography 2019-2024, whose aims are to evaluate and determine the demand for statistical and geographic information, analyze relevant and current information, and integrate the state catalog of indicators. 
Author Contributions: Conceptualization, I.L.-G.; methodology, I.L.-G.; software, I.L.-G., D.H.-P. and R.M.-G.; validation, M.G.H.-O., D.H.-P. and R.M.-G.; formal analysis, M.G.H.-O.; investigation, I.L.-G. and M.G.H.-O.; resources, M.G.H.-O.; data curation, I.L.-G., M.G.H.-O., D.H.-P., R.M.-G. and D.M.-C.; writing-original draft preparation, I.L.-G.; writing—review and editing, M.G.H.-O.; visualization, I.L.-G.; supervision, M.G.H.-O.; project administration, I.L.-G.; funding acquisition, I.L.-G., M.G.H.-O. and D.M.-C. All authors have read and agreed to the published version of the manuscript.

Funding: This research was funded by the National Council of Science and Technology (CONACYT): 2020-000026-02NACF-01216 within the framework of the doctoral thesis "Regionalization model for the centralized promotion of institutional capacities in municipal governments of the State of Veracruz, Mexico".

Institutional Review Board Statement: Not applicable.

Informed Consent Statement: Not applicable.

Data Availability Statement: The publicly archived datasets analyzed during the study were consulted at: https://www.mx.undp.org/content/dam/mexico/docs/Publicaciones/PublicacionesRed uccionPobreza/InformesDesarrolloHumano/idhmunicipal20102015/IDHMunicipal\%20Bases\%20d e\%20datos\%20y\%20programas\%20de\%20calculo.zip and https://www.inegi.org.mx/contenidos/pr oductos/prod_serv/contenidos/espanol/bvinegi/productos/geografia/marcogeo/889463807469/3 0_veracruzignaciodelallave.zip; in both cases, accessed on 31 January 2021.

Conflicts of Interest: The authors declare no conflict of interest.

\section{Appendix A}

Table A1. Projects alignment.

International:

Sustainable Development Goals [63]

Goal 11: Sustainable cities and communities

Goal 16: Peace, justice, and strong institutions.

National:

\section{Cross-curricular axes:}

Fighting corruption and improving public management

Territory and sustainable development

National Development Plan 2019-2024 [64]

Sectoral Programs 2020-2024 [65]
General axis: Well-being

Goal 2.5: Guarantee the right to a healthy environment with a focus on the sustainability of ecosystems, biodiversity, heritage, and biocultural landscapes

Strategy 2.5.5: articulate governmental action to contribute to environmental public management with a focus on territoriality, sustainability, human rights, and gender.

Governance sectoral program

Priority goal 6: Strengthen federalism, decentralization, and municipal development.

Sectoral program for agrarian, territorial, and urban development

Priority goal 1: Establish an integrated, orderly, inclusive, sustainable, and safe territorial system.

National Program to Combat Corruption and Impunity and to Improve Public Management 2019-2024

Goal 3: Promote the efficiency and effectiveness of public management.

Goal 4: Promote the professionalization and efficient management of the human resources of the Federal Public Administration.

National Strategic Program in Socio-ecological Systems and Sustainability.

Theme: Design of sustainable territorial socio-ecological planning instruments, adaptation measures to global change (for example, urban development plans, territorial ordinances). Institutional Program 2020-2024 of the National Council of Science and Technology Priority objective 5: Articulate and strengthen the scientific, humanistic and technological capacities of the country by linking with regional actors to influence strategic national problems in favor of social benefit, environmental care, biocultural diversity, and common goods. 
Table A1. Cont.

\section{State:}

Veracruz Development Plan 2019-2024 [47]

State Program of Statistics and Geography 2019-2024 [66]
Block: Politics and Government

Goal: Project the political development of the State of Veracruz.

Block: Social welfare

Goal: Contribute to the social welfare of subjects of law

Project I.2: Analysis to determine the demand for statistical and geographic information in the State.

Project V.2.7: Establish the Interactive Consultation of Municipal Information (CIIM)

Project V.2.9: Carry out analysis documents with relevant information and/or situation of the State.

Project V.2.9: Make the Catalog of indicators.

\section{Appendix B}

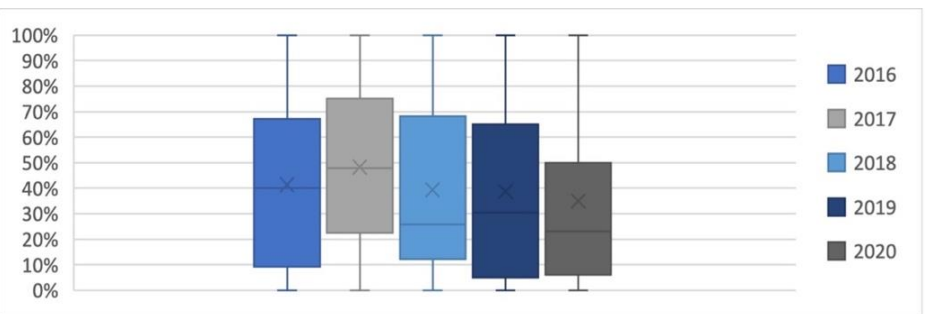

Figure A1. Historical participation of the states in federal programs for the development of MIC, 2016-2020.

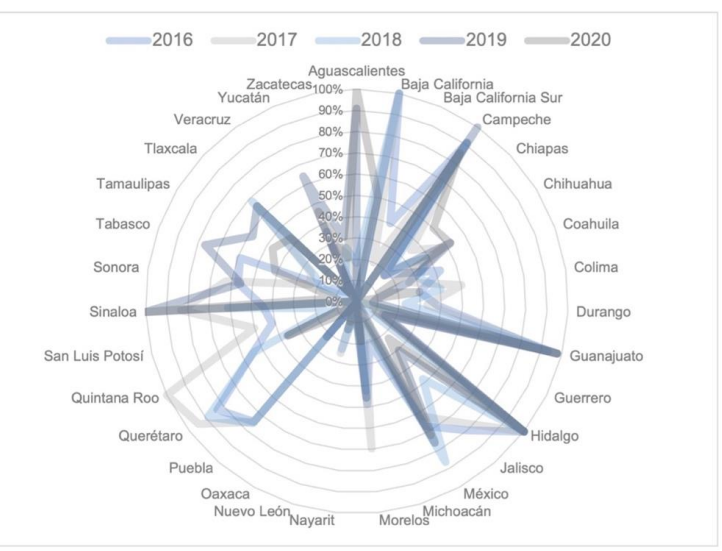

Figure A2. Participation of the states in federal programs for the development of MIC, 2016-2020.

Table A2. Performance of the participation of the State of Veracruz in federal programs for the development of MIC, 2016-2020.

\begin{tabular}{ccc}
\hline Year & $\begin{array}{c}\text { Place According to Its } \\
\text { Participation }\end{array}$ & $\begin{array}{c}\text { \% of Municipalities That } \\
\text { Participate }\end{array}$ \\
\hline 2020 & 1st lowest place & 4 \\
2019 & 1st lowest place & ** \\
2018 & 1st lowest place *** & 4 \\
2017 & 2nd lowest place & 2 \\
2016 & 2nd lowest place & 2 \\
\hline
\end{tabular}

* They did not participate: San Luis Potosí, Baja California Sur, Durango and Oaxaca. ${ }^{* *}$ They did not participate: Baja California, Querétaro, Michoacán, San Luis Potosí, Baja California Sur and Oaxaca. *** They did not participate: Oaxaca, Sonora, Guerrero and Baja California Sur. ${ }^{* * * *}$ Below only Oaxaca. Nayarit did not participate. ***** Only Zacatecas below. They did not participate: Oaxaca, Nuevo León, Aguascalientes and Nayarit. Source: Authors' elaboration based on INAFED [22-25]. 


\section{Appendix C}

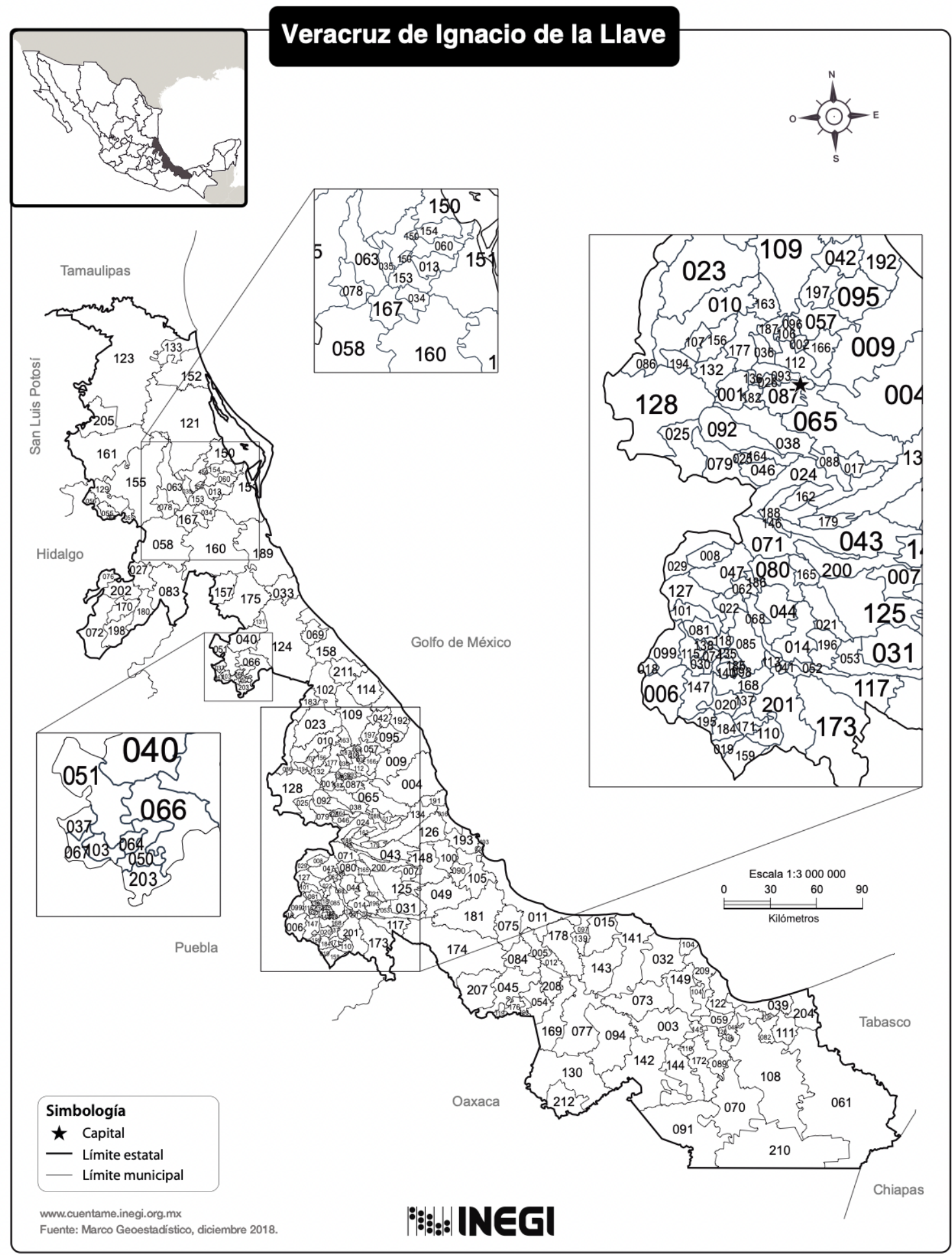

Figure A3. Cont. 


\section{Veracruz de Ignacio de la Llave}

\section{Municipios:}

001 Acajete
002 Acatlán
003 Acayucan
004 Actopan
005 Acula
006 Acultzingo
007 Camarón de Tejeda
008 Alpatláhuac
009 Alto Lucero de Gutiérrez Barrios
010 Altotonga
011 Alvarado
012 Amatitlán
013 Naranjos Amatlán
014 Amatlán de los Reyes
015 Angel R. Cabada
016 La Antigua
017 Apazapan
018 Aquila
019 Astacinga
020 Atlahuilco
021 Atoyac
022 Atzacan
023 Atzalan
024 Tlaltetela
025 Ayahualulco
026 Banderilla
027 Benito Juárez
028 Boca del Río
029 Calcahualco
030 Camerino Z. Mendoza
031 Carrillo Puerto
032 Catemaco
033 Cazones
034 Cerro Azul
035 Citlaltépetl
036 Coacoatzintla
037 Coahuitlán
038 Coatepec
039 Coatzacoalcos
040 Coatzintla
041 Coetzala
042 Colipa
043 Comapa
044 Córdoba
045 Cosamaloapan de Carpio
046 Cosautlán de Carvajal
047 Coscomatepec
048 Cosoleacaque
049 Cotaxtla
050 Coxquihui
051 Coyutla
052 Cuichapa
053 Cuitláhuac
054 Chacaltianguis
055 Chalma
056 Chiconamel
057 Chiconquiaco
058 Chicontepec
059 Chinameca
060 Chinampa de Gorostiza
061 Las Choapas
062 Chocamán
063 Chontla
064 Chumatlán
065 Emiliano Zapata
066 Espinal

066 Espinal

\begin{tabular}{|c|c|c|c|}
\hline 067 & Filomeno Mata & 133 & Pueblo Viejo \\
\hline 068 & Fortín & 134 & Puente Nacional \\
\hline 069 & Gutiérrez Zamora & 135 & Rafael Delgado \\
\hline 070 & Hidalgotitlán & 136 & Rafael Lucio \\
\hline 071 & Huatusco & 137 & Los Reyes \\
\hline 072 & Huayacocotla & 138 & Río Blanco \\
\hline 073 & Hueyapan de Ocampo & 139 & Saltabarranca \\
\hline 074 & Huiloapan & 140 & San Andrés Tenejapan \\
\hline 075 & Ignacio de la Llave & 141 & San Andrés Tuxtla \\
\hline 076 & llamatlán & 142 & San Juan Evangelista \\
\hline 077 & Isla & 143 & Santiago Tuxtla \\
\hline 078 & Ixcatepec & 144 & Sayula de Alemán \\
\hline 079 & Ixhuacán de los Reyes & 145 & Soconusco \\
\hline 080 & Ixhuatlán del Café & 146 & Sochiapa \\
\hline 081 & Ixhuatlancillo & 147 & Soledad Atzompa \\
\hline 082 & Ixhuatlán del Sureste & 148 & Soledad de Doblado \\
\hline 083 & Ixhuatlán de Madero & 149 & Soteapan \\
\hline 084 & Ixmatlahuacan & 150 & Tamalín \\
\hline 085 & Ixtaczoquitlán & 151 & Tamiahua \\
\hline 086 & Jalacingo & 152 & Tampico Alto \\
\hline 087 & Xalapa & 153 & Tancoco \\
\hline 088 & Jalcomulco & 154 & Tantima \\
\hline 089 & Jáltipan & 155 & Tantoyuca \\
\hline 090 & Jamapa & 156 & Tatatila \\
\hline 091 & Jesús Carranza & 157 & Castillo de Teayo \\
\hline 092 & Xico & 158 & Tecolutla \\
\hline 093 & Jilotepec & 159 & Tehuipango \\
\hline 094 & Juan Rodríguez Clara & 160 & Temapache \\
\hline 095 & Juchique de Ferrer & 161 & Tempoal \\
\hline 096 & Landero y Coss & 162 & Tenampa \\
\hline 097 & Lerdo de Tejada & 163 & Tenochtitlán \\
\hline 098 & Magdalena & 164 & Teocelo \\
\hline 099 & Maltrata & 165 & Tepatlaxco \\
\hline 100 & Manlio Fabio Altamirano & 166 & Tepetlán \\
\hline 101 & Mariano Escobedo & 167 & Tepetzintla \\
\hline 102 & Martínez de la Torre & 168 & Tequila \\
\hline 103 & Mecatlán & 169 & José Azueta \\
\hline 104 & Mecayapan & 170 & Texcatepec \\
\hline 105 & Medellin & 171 & Texhuacán \\
\hline 106 & Miahuatlán & 172 & Texistepec \\
\hline 107 & Las Minas & 173 & Tezonapa \\
\hline 108 & Minatitlán & 174 & Tierra Blanca \\
\hline 109 & Misantla & 175 & Tihuatlán \\
\hline 110 & Mixtla de Altamirano & 176 & Tlacojalpan \\
\hline 111 & Moloacán & 177 & Tlacolulan \\
\hline 112 & Naolinco & 178 & Tlacotalpan \\
\hline 113 & Naranjal & 179 & Tlacotepec de Mejía \\
\hline 114 & Nautla & 180 & Tlachichilco \\
\hline 115 & Nogales & 181 & Tlalixcoyan \\
\hline 116 & Oluta & 182 & Tlalnelhuayocan \\
\hline 117 & Omealca & 183 & Tlapacoyan \\
\hline 118 & Orizaba & 184 & Tlaquilpa \\
\hline 119 & Otatitlán & 185 & Tlilapan \\
\hline 120 & Oteapan & 186 & Tomatlán \\
\hline 121 & Ozuluama de Mascare \pm as & 187 & Tonayán \\
\hline 122 & Pajapan & 188 & Totutla \\
\hline 123 & Pánuco & 189 & Túxpam \\
\hline 124 & Papantla & 190 & Tuxtilla \\
\hline 125 & Paso del Macho & 191 & Ursulo Galván \\
\hline 126 & Paso de Ovejas & 192 & Vega de Alatorre \\
\hline 127 & La Perla & 193 & Veracruz \\
\hline 128 & Perote & 194 & Villa Aldama \\
\hline 129 & Platón Sánchez & 195 & Xoxocotla \\
\hline 130 & Playa Vicente & 196 & Yanga \\
\hline 131 & Poza Rica de $\mathrm{Hi}$ & 197 & Yecuatla \\
\hline 132 & Las Vigas de Ramírez & 198 & Zacualpan \\
\hline
\end{tabular}

200 Zentla

202 Zontecomatlán de López y Fuentes 203 Zozocolco de Hidalgo

204 Agua Dulce

205 El Higo

206 Nanchital de Lázaro Cárdenas del Río 207 Tres Valles

208 Carlos A. Carrillo

209 Tatahuicapan de Juárez

210 Uxpanapa

212 Santiago Sochiapan

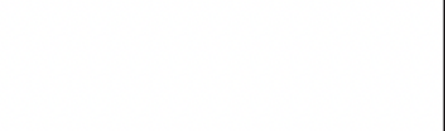




\section{Appendix D}

Spatial analysis using first-order rook-type contiguity matrix.

Table A3. Properties of the first-order rook-type contiguity matrix.

\begin{tabular}{ll}
\hline Property & Value \\
Type & Rook \\
Symmetry & Symmetric \\
File & ICFM_2016Torre.gal \\
Id variable & CVEGEO \\
Order & 1 \\
\# Observations & 212 \\
Min neighbors & 1 \\
Max neighbors & 12 \\
Mean neighbors & 5.10 \\
Median neighbors & 5.00 \\
\% Non-zero & $2.41 \%$
\end{tabular}

Source: Authors' elaboration in GeoDa 1.18.

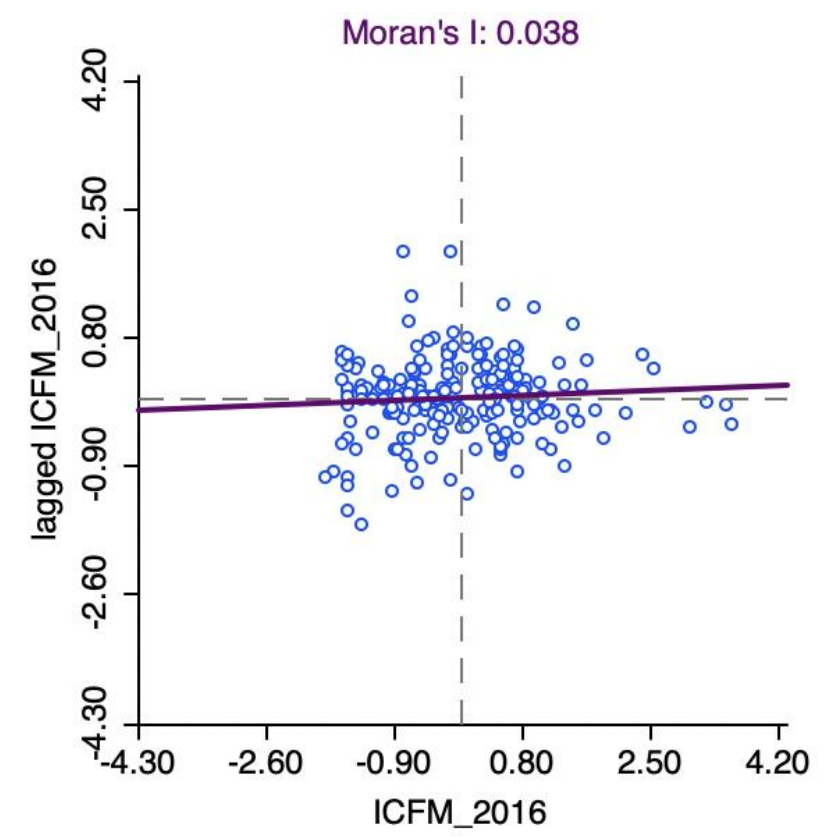

Figure A4. Moran's Index. First-order rook-type physical contiguity. Designed on GeoDa 1.18.

permutations: 999

pseudo p-value: 0.155000

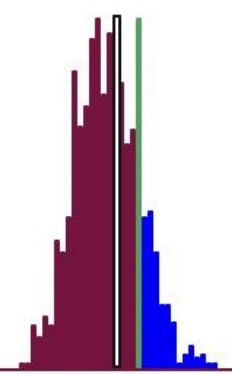

I: 0.0383 E[I]: -0.0047 mean: -0.0074 sd: 0.0442 z-value: 1.0327

Figure A5. Reference statistical distribution graphic. Designed on GeoDa 1.18. 


\section{References}

1. Rosas Huerta, A. Una ruta metodológica para evaluar la capacidad institucional. Política Y Cult. 2008, 30, 119-134.

2. Pearson, J. Metropolitan Governance:A Framework for Capacity Assessment Guidance Notes and Toolbox; Deutsche Gesellschaft für Internationale Zusammenarbeit (GIZ) GmbH: Eschborn, Germany, 2016.

3. Aguilar Villanueva, L.F. Gobierno y Desarrollo. Iberoforum. Rev. Cienc. Soc. Univ. Iberoam. 2007, 2, 1-20.

4. ASF Desarrollo Institucional Municipal; Auditoría Superior de la Federación: Ciudad de México, México 2015. Available online: http:/ / 200.23.8.25/ASF/?m=bWVudSww (accessed on 6 June 2021).

5. Grindle, M.S. Good Enough Governance Revisited. Dev. Policy Rev. 2007, 25, 533-574. [CrossRef]

6. OECD. Building Capacity for Evidence-Informed Policy-Making: Lessons from Country Experiences; OECD Public Governance Reviews; OECD: Paris, France, 2020; ISBN 978-92-64-53757-6.

7. UNDP. Informe de Desarrollo Humano Municipal 2010-2015 Transformando México Desde Lo Local; UNDP: New York, NY, USA, 2019; p. 348.

8. Pulfer, G. Dilemmas of State Building in a Fragile Context. In Democratic Governance Insights. Issues 1-12; Democratic Governance Practice Network (DGP-NET): New York, NY, USA, 2011.

9. SEFIPLAN Índice de Desarrollo Humano 2010 y 2015 y Capacidades Funcionales de Los Municipios 2016. Principales Resultados Para El Estado de Veracruz; Secretaría de Finanzas y Planeación. Subsecretaría de Planeación: Veracruz, México, 2019.

10. UNDP. Capacity Assessment. Practice Note; UNDP: New York, NY, USA, 2008.

11. USAID. CITIES Municipal Institutional Capacity Assessment (MICA) Final Report; USAID/Jordan: Washington, DC, USA, 2017.

12. UNDP. Measuring Capacity; United Nations Development Programme: New York, NY, USA, 2010.

13. Grindle, M.S.; Hilderbrand, M.E. Building Sustainable Capacity in the Public Sector: What Can Be Done? Public Adm. Dev. 1995, 15, 441-463. [CrossRef]

14. Montañez Gómez, G.; Delgado Mahecha, O. Espacio, Territorio y Región: Conceptos Básicos Para Un Proyecto Nacional. Cuad. Geogr. Rev. Colomb. Geogr. 1998, 7, 120-134.

15. Nohlen, D.; Sturm, R. La heterogeneidad estructural como concepto básico de la teoría de desarrollo. Rev. Estud. Políticos 1982, 28, 45-74.

16. Wallis, J.; Dollery, B. Social Capital and Local Government Capacity. Aust. J. Public Adm. 2002, 61, 76-85. [CrossRef]

17. Completa, E.R. Capacidad Estatal, Brechas de Capacidad y Fortalecimiento Institucional. Análisis Político 2016, $29,60-76$. [CrossRef]

18. Cohen, J.M. Capacity Building in the Public Sector: A Focused Framework for Analysis and Action. Int. Rev. Adm. Sci. 1995, 61, 407-422. [CrossRef]

19. Gargantini, D.M.; Pedrotti, C.I. Capacidades institucionales del gobierno municipal en el diseño y gestión de políticas habitacionales. Econ. Soc. Y Territ. 2018, 18, 319-357. [CrossRef]

20. Pribble, J. The Politics of Building Municipal Institutional Effectiveness in Chile. Lat. Am. Politics Soc. 2015, 57, 100-121. [CrossRef]

21. Moreno Jaimes, C. Para entender el desarrollo de las capacidades institucionales en los gobiernos municipales en México. Buen Gob. 2008, 5, 49-61. [CrossRef]

22. INAFED. Resultados del Programa Agenda para el Desarrollo Municipal 2017; 2017. Available online: http://www.gob.mx/ina fed/documentos / resultados-del-programa-agenda-para-el-desarrollo-municipal-2017 (accessed on 6 June 2021).

23. INAFED. Resultados del Programa Agenda para el Desarrollo Municipal 2018; 2018. Available online: http://www.gob.mx/ina fed/documentos / resultados-del-programa-agenda-para-el-desarrollo-municipal-2018-183273 (accessed on 6 June 2021).

24. INAFED Resultados GDM. SiGuía 2020. Available online: http:/ / siglo.inafed.gob.mx/siguia/index.php (accessed on 6 June 2021).

25. INAFED. Participación de cada estado en el programa Agenda para el Desarrollo Municipal 2016. Available online: http: //www.gob.mx/inafed/documentos/participacion-de-cada-estado-en-adm-2016 (accessed on 6 June 2021).

26. Giraudy, A.; Moncada, E.; Snyder, R. El Análisis Subnacional: Aportes Teóricos y Metodológicos a La Política Comparada. Rev. Cienc. Política 2021, 41, 1-34. [CrossRef]

27. Harbers, I.; Ingram, M.C. Politics in Space: Methodological Considerations for Taking Space Seriously in Subnational Research. In Inside Countries: Subnational Research in Comparative Politics; Giraudy, A., Moncada, E., Snyder, R., Eds.; Cambridge University Press: Cambridge, UK, 2019; pp. 57-91; ISBN 978-1-108-49658-2.

28. Acevedo Bohórquez, I.; Velásquez Ceballos, E. Algunos Conceptos de La Econometría Espacial y El Análisis Exploratorio de Datos Espaciales. Rev. Ecos Econ. 2008, 12, 9-34.

29. Hernández Sampieri, R.; Fernández Collado, C.; Baptista Lucio, M.d.P. Metodología de La Investigación, 6th ed.; McgrawHill/Interamericana Ed.: Mexico City, México, 2014; ISBN 978-1-4562-2396-0.

30. Mujica, N.; Rincón, S. Bases constitutivas de un modelo de desarrollo alternativo para Venezuela. Telos 2016, 18, 431-453.

31. Beltrán Saravia, V. Diagnóstico del déficit de capacidad institucional de los procesos para el rediseño organizacional en el sector público. Perf. Ing. 2015, 11, 11. [CrossRef]

32. Oszlak, O.; Orellana, E. El Análisis de La Capacidad Institucional: Aplicación de La Metodología SADCI. 1993. Available online: http:/ / www.top.org.ar/Documentos/OSZLAK,\%20Oscar\%20y\%20ORELLANA,\%20Edgardo\%20-\%20El\%20análisis $\% 20 \mathrm{de} \% 201 \mathrm{\%} \% 20$ capacidad $\% 20$ institucional.pdf (accessed on 6 June 2021). 
33. Jaime, F.; Vaca Avila, P. Las políticas basadas en evidencia como plataformas para la innovación de políticas públicas. Estado Abierto. Rev. Sobre El Estado La Adm. Y Las Politicas Públicas 2017, 2, 51-76.

34. Siabato, W.; Guzmán-Manrique, J. La Autocorrelación Espacial y El Desarrollo de La Geografía Cuantitativa. Cuad. Geogr. Rev. Colomb. Geogr. 2019, 28, 1-22. [CrossRef]

35. González Pérez, M.; Pérez Coello, L.; Castro Contreras, E.B. Diagnóstico de las capacidades funcionales en el contexto local (Original). Redel. Rev. Granmense Desarro. Local 2019, 3, 138-151.

36. Santos Assan, A.H.; Gallardo Milanés, O.A. Desarrollo humano a escala local: Experiencias en el municipio Urbano Noris, Holguín/Cuba. Revista NUPEM 2017, 9, 26-37. [CrossRef]

37. Valencia Pozo, C.A. Gestión Municipal y Desarrollo Local en el Distrito de Chavín de Huantar, 2017; Tesis de Maestría en Gestión Pública, Universidad Cesar Vallejo: Lima, Perú, 2017.

38. Vera Lara, E. Innovación Institucional en el Gobierno Municipal de la Provincia de Jaén, Para la Gestión del Desarrollo Económico Local, Jaén-Cajamarca, 2015-2016; Tesis de Doctorado en Gestión Pública y Gobernabilidad, Universidad Cesar Vallejo: Lima, Perú, 2017.

39. Palacios Rojas, D.M. Gestión municipal y desarrollo local de la Provincia de Chupaca del Departamento de Junín-2016; Tesis de Maestría en Administración Pública y Gobierno, Universidad Nacional del Centro del Perú: Huancayo, Perú, 2018.

40. Peña Mcguire, J. Factores Que Influyen en la Gestión de las Políticas de Desarrollo Económico Local en la Municipalidad Distrital de Matapalo-Tumbes 2015-2016; Tesis de Maestría en Gestión Pública, Universidad Nacional de Tumbes: Tumbes, Perú, 2018.

41. Vare Polo, E.R. Gestión Municipal y Desarrollo Local en el distrito de Supe, 2017; Tesis Licenciatura en Sociología, Universidad Nacional José Faustino Sánchez Carrión: Lima, Perú, 2017.

42. Guzmán Gil, P.D.; Becerril Sánchez, T. El desarrollo de capacidades institucionales ante los retos de la coordinación metropolitana en México: El caso de Toluca. Decumanus 2019, 4, 4. [CrossRef]

43. International Organization for Standardization ISO 18091:2019(en) Quality Management Systems—Guidelines for the Application of ISO 9001 in Local Government. Available online: https://www.iso.org/obp/ui\#tiso:std:iso:18091:ed-2:v1:en (accessed on 27 November 2021).

44. INAFED Instituto Nacional Para El Federalismo y El Desarrollo Municipal. Available online: https://www.gob.mx/inafed (accessed on 16 June 2021).

45. Kientz, D.G. Regionalización geomorfológica del estado de Veracruz. Investig. Geográficas (Mx) 1999, $40,23-47$.

46. Chiappy Jhones, C.J.; Gama, L.; Soto Esparza, M.; Geissert, D.; Chávez, J. Regionalización Paisajística Del Estado de Veracruz, México. Univ. Y Cienc. 2002, 18, 87-113.

47. Poder Ejecutivo. Plan Veracruzano de Desarrollo 2019-2024; Gobierno del Estado: Veracruz, México, 2019; Available online: http:/ /repositorio.veracruz.gob.mx/wp-content/uploads/sites/4/files/transp/pvd_2019_2024/Gac2019-224_Miercole S_05_TOMO_II_Ext_(PLAN_VERACRUZANO_2019_2024).pdf (accessed on 27 November 2021).

48. Gobierno de Estado de Veracruz. Nueva Normalidad. 2021. Available online: http:// coronavirus.veracruz.gob.mx/nueva-norm alidad/ (accessed on 27 November 2021).

49. CEIEG-SEFIPLAN Documentos de Análisis I Estudios Regionales para la Planeación. Available online: http:/ / ceieg.veracruz.gob .mx/2019/10/07/documentos-de-analisis/ (accessed on 12 January 2021).

50. INEGI Marco Geoestadístico. Censo de Población y Vivienda 2020. Available online: https://www.inegi.org.mx/app/biblioteca/ ficha.html?upc $=889463807469$ (accessed on 21 June 2021).

51. Getis, A. Spatial Autocorrelation. In Handbook of Applied Spatial Analysis; Fischer, M.M., Getis, A., Eds.; Springer: Berlin/Heidelberg, Germany, 2010; pp. 255-278. ISBN 978-3-642-03646-0.

52. Mendoza, J.A.H. Taller de Análisis de Datos Espaciales con Geoda. Índice Global y Local de Moran; UNAM-CEDRUS: Ciudad de México, México, 2020; Available online: https: / www.youtube.com/watch?v=mp2uPNF51D4 (accessed on 21 June 2021).

53. Anselin, L.; Syabri, I.; Kho, Y. Geoda: An Introduction to Spatial Data Analysis. In Handbook of Applied Spatial Analysis: Software Tools, Methods and Applications; Fischer, M.M., Getis, A., Eds.; Springer: Berlin/Heidelberg, Germany, 2010 ; pp. 73-89. ISBN 978-3-642-03647-7.

54. Celemín, J.P. Autocorrelación espacial e indicadores locales de asociación espacial. Importancia, estructura y aplicación. Rev. Univ. Geogr. 2009, 18, 11-31.

55. Minitab. Entendiendo las Pruebas de Hipótesis: Niveles de Significancia (Alfa) y Valores P en Estadística. 2021. Available online: https:/ /blog.minitab.com/es/entendiendo-las-pruebas-de-hipotesis-niveles-de-significancia-alfa-y-valores-p-en-esta distica (accessed on 21 June 2021).

56. Anselin, L. SpaceStat TUTORIAL A Workbook for Using SpaceStat in the Analysis of Spatial Data. 1992. Available online: https:/ / web.worldbank.org/archive/website01407/WEB/IMAGES/ANSELIN_.PDF (accessed on 21 June 2021).

57. Cliff, A.D.; Ord, K. Spatial Autocorrelation: A Review of Existing and New Measures with Applications. Econ. Geogr. 1970, 46, 269-292. [CrossRef]

58. Talen, E.; Anselin, L. Assessing Spatial Equity: An Evaluation of Measures of Accessibility to Public Playgrounds. Environ. Plan. A Econ. Space 1998, 30, 595-613. [CrossRef]

59. Johnson, R.; Kuby, P. Estadística Elemental: Lo Esencial, 10th ed.; Cengage Learning Editores: Ciudad de México, México, 2008; ISBN 13: 978-607-481-199-5.

60. Rawls, J. A Theory of Justice; Harvard University Press: Cambridge, MA, USA, 2020; ISBN 0-674-04260-3. 
61. Sen, A. Equality of What. Tann. Lect. Hum. Values 1979, 1, 197-220.

62. Chou, Y.-H. Spatial Pattern and Spatial Autocorrelation. In Proceedings of the Spatial Information Theory A Theoretical Basis for GIS; Frank, A.U., Kuhn, W., Eds.; Springer: Berlin/Heidelberg, Germany, 1995; pp. 365-376.

63. UN, D. of E. and S.A. THE 17 GOALS I Sustainable Development. Available online: https://sdgs.un.org/goals (accessed on 16 January 2022).

64. Secretaría de Gobernación. Plan Nacional de Desarrollo 2019-2024; Secretaría de Gobernación: Ciudad de México, Mexico, 2019; p. 225.

65. Gobernación. Programas Sectoriales 2019-2024; Gobierno de México: Ciudad de México, México, 2019; Available online: http: //www.ordenjuridico.gob.mx/sectoriales.php\#gsc.tab=0 (accessed on 21 June 2021).

66. CEIEG. Programa Estatal de Estadística y Geografía Del Estado de Veracruz de Ignacio de La Llave (PEEG) 2019-2024; CEIEG: Xalapa, Mexico, 2019.

67. INEGI Municipal Division Map of the State of Veracruz, Mexico; Cuéntame; 2018. Available online: http://cuentame.inegi.org.m x/mapas/pdf/entidades/div_municipal/veracruzmpios.pdf (accessed on 21 June 2021). 